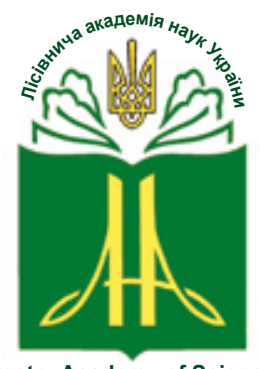

Forestry Academy of Sciences of Ukraine

Наукові праці Лісівничої академії наук України Proceedings of the Forestry Academy of Sciences of Ukraine

http://fasu.nltu.edu.ua https://doi.org/10.15421/411932

Article received 2019.05.11

Article accepted 2019.12.26
ISSN 1991-606X print

ISSN 2616-5015 online

(a) $\triangle$ Correspondence author

Svitlana Raspopina

s_raspopina@ukr.net

Kharkiv region, Kharkiv district, the village of «Dokuchaevske-2» 62483, Ukraine

УДК 630*91: 631.459 .3

\title{
Піщані ґрунти та стан лісорозведення у зоні інтенсивної дефляції України
}

\author{
С.П. Распопіна'
}

Надмірна розораність земель Украӥни спричинила інтенсивний розвиток ерозійних процесів $і$ як наслідокдеградацію ї̈ трунтового покриву. Для зупинення процесу деградайї необхідно вилучити з обробітку від 6,5 до 10 млн га малопродуктивних земель, здебільшого у Степу, територія якого є найбільш розораною. Частину вилучених земель передають під заліснення. 3'ясовано, що найбільші обсяги лісорозведення останніх десятиліть збігаються з виконанням Державної иільової програми «Ліси України» на 2010-2015 рр., упродовж якої під заліснення було прийнято близько 210 тис. га малопродуктивних земель, здебільшого (понад 190 тис. га) держлісгоспами степового регіону. На 01.01.2019 р. загальна площа прийнятих, але незаліснених земель, зменшилась до 44777 га, причому абсолютно більша їх частина (96,9\%) припадає на держлісгоспи у Степу. Наведено показники приживлюваності та збережуваності лісових культур, створених під час лісорозведення у иій природнокліматичній зоні, які є значно нижчими за нормативні. Показано, щзо максимальні площі загиблих культур у Степу зосереджені на територіях держсавних лісогосподарських підприємствах Донецького, Миколаївського та особливо Херсонського ОУЛМГ. Охарактеризовано дернові опідзолені піщані трунти, які, унаслідок вкрай несприятливих для сільськогосподарських культур властивостей (безструктурність, низькі вологоємність, гумусованість, трофність тощо), значною мірою передають під заліснення. Доведено, що рівень їхньої родючості иілком залежить від вмісту глинистих часток. Запропоновано маркери для визначення як дефляційного впливу на трунти піщаного складу, так і їхньої лісотипологічної оцінки.

Ключові слова: вітрова ерозія; степ; малопродуктивні землі; заліснення; лісові культури; вміст фізичної глини.

Вступ. Ситуація, що нині склалася з ефективним використанням земель в Україні, близька до критичної. Надмірна розораність земель (близько $57 \%$ території) зумовила значне зниження стійкості агроландшафтів до несприятливих природних чинників, зокрема спричинила інтенсивний розвиток ерозійних процесів і як наслідок - деградацію грунтового покриву. Площі земель країни, які потерпають від дії водної ерозії, становлять 13,3 млн га, дефляції - 6 млн га, а в роки із масштабними пиловими бурями - 20 млн га (Baliuk \& Tovazhnianskyi, 2010). У березні 2007 р. зафіксовано одну із наймасштабніших в Україні пилових бур останніх років, яка охопила 20\% території України: частину Одеської, всю Миколаївську, Херсонську, Запорізьку області, північ Автономної Республіки Крим, південні райони Кіровоградської й Дніпропетровської та західні Донецької областей. Втрати грунту з не вкритої рослинністю площі в епіцентрі пилової бурі становили 150-400 т $\cdot \mathrm{ra}^{-1}$ (Chornyi \& Chorna, 2008), а загалом

Распопіна Світлана Петрівна - член-кореспондент Лісівничої академії наук України, доктор сільськогосподарських наук, старший науковий співробітник, завідувачка кафедри лісових культур і меліорацій. Харківський національний аграрний університет ім. В. В. Докучаєва, п/в «Докучаєвське-2» Харківської обл., 62483, Україна. Тел.: 0572-99-72-56, +38-068-459-64-23. E-mail: s_raspopina@ukr.net ORCID: http://orcid.org/ 0000-0002-1880-9364 
від ерозії в Україні щорічно втрачається чистого доходу сільськогосподарського виробництва майже на 3 млрд доларів США (Sayko, 2008).

Найдієвішим засобом зупинення та запобігання деградації грунтів $є$ оптимізація співвідношення площі ріллі й екологічно стабілізуючих угідь. Вона досягається шляхом вилучення з обробітку деградованих і малопродуктивних земель із наступною їхньою консервацією й трансформацією у лісові та кормові угіддя. За різними оцінками (Baliuk \& Tovazhnianskyi, 2010), вилучення потребує від 6,5 до 10 млн га ріллі, здебільшого у Степу, територія якого найбільш розорана (табл. 1).

\section{Таблиия 1}

Розораність (поточна та оптимальна) сільськогосподарських угідь степової зони за адміністративними областями України, \%

\begin{tabular}{lcc}
\hline \multicolumn{1}{c}{ Область } & Поточна & Оптимальна \\
\hline Луганська & 77 & 41 \\
Дніпропетровська & 88 & 44 \\
Донецька & 71 & 66 \\
Запорізька & 88 & 36 \\
Кіровоградська & 89 & 56 \\
Миколаївська & 88 & 32 \\
Одеська & 85 & 39 \\
Херсонська & 87 & 23 \\
\hline
\end{tabular}

Визначено, що для рівнинної частини України оптимальне співвідношення між площею ріллі, кормових угідь і лісів має становити $1: 1,6: 3,6$, а лісистість території Степу залежно від умов зволоження - від 5,3 до 10,6\%, а фактично зазначене співвідношення становить $1: 0,2: 0,3$ (Biallovich, 1972), а лісистість - 3,7-6,9\%. Одним із стратегічних завдань лісового господарства України є збільшення лісистості території до нормативного рівня $-20 \%$ (State Target Program «Forests of Ukraine», 2010). Для його досягнення необхідно додатково заліснити щонайменше 2,5 млн га земель, причому це здебільшого виведені 3-під сільськогосподарського користування малопродуктивна рілля та різні види деградованих грунтів.

У Степу України одними із основних видів малопродуктивних грунтів $\epsilon$ грунти легкого гранулометричного складу, зокрема дернові опідзолені на давньоалювіальних або еолових пісках (Gladkiy, 1960, Gael \& Smirnova, 1999). У цій зоні піщані грунти, зважаючи на їхню сухість, $є$ безперспективними для використання у сільськогосподарському виробництві, водночас на них формуються типи лісорослинних умов, придатні для росту соснових насаджень, які виконують важливі різноманітні захисні функції та, подекуди, є доволі продуктивними. Рівень трофності місцезростань залежить від вмісту глинистих часток та підвищується з його зростанням у межах від борового до сугрудового типів (Raspopina, 2017). Лісорозведення на прийнятих держлісгоспами землях потрібно проводити 3 максимальним урахуванням лісорослинного потенціалу грунтів (Raspopina, 2017). Особливо це стосується піщаних грунтів, розташованих у зоні впливу несприятливих природно-кліматичних умов та небезпечних процесів, зокрема дефляції, які зумовлюють їхню деградацію (Prymak, 2001).

На піщаних землях, переданих у лісомеліоративний фонд, здебільшого створюють ліси захисногосподарського призначення, захисні насадження для закріплення рухомих пісків, культури спеціального призначення (вербові плантації тощо) (Dryuchenko, 1962). Черговість заліснення піщаних ділянок визначають залежно від господарської доцільності. Так, наприклад, рухомі піски, які загрожують засипанням господарських об'єктів, мають пріоритет заліснювання. Загалом найбільші масиви піщаних грунтів розташовані у південно-східній частині України, де під дією природних чинників сформувалася зона активної дефляції. Останнім часом тут, унаслідок потужного впливу антропогенного чинника, зокрема надмірної розораності території, поряд 3 інтенсивним знищенням деревної рослинності (здебільшого через лісові пожежі та несанкціоновані вирубки), відбувається активізація ерозійних процесів. 3 огляду на значну дефляційну вразливість та вкрай низький рівень родючості піщаних грунтів південно-східної частини України, оцінювання рівня еродованості та загалом їхнього лісорослинного потенціалу є особливо актуальною проблемою.

Об'скти та методика дослідження. Об 'єкт дослідження - лісорозведення та піщані грунти в умовах Лівобережного Степу України. Предмет дослідження - стан лісорозведення і трансформація властивостей піщаних грунтів у провінції інтенсивної дефляції України. Мета роботи - оцінити стан лісорозведення та властивості піщаних грунтів у провінції інтенсивної дефляції (Луганська та Херсонська області), запропонувати маркери для визначення ступеня їхньої дефляції та лісотипологічної оцінки.

Стан лісорозведення у степових умовах України оцінювали на основі аналізу статистичних даних Держлісагентства України щодо обсягів лісорозведення, приживлюваності та збережуваності 1-3-річних лісових культур за окремими обласними управліннями лісового та мисливського господарств (ОУЛМГ) степового регіону.

Властивості піщаних грунтів (натурні та лабораторні) оцінювали на прикладі дернових опідзолених грунтів на давньоалювіальних (еолових) пісках і примітивних грунтів початкових стадій формування, розташованих у зоні інтенсивної дефляції (південний схід України). Натурні - за методикою польових досліджень грунтів (Polupan et al., 1981) на землях державних лісогосподарських підприємств Харківського, Луганського, Херсонського ОУЛМГ, лабораторні - за загальноприйнятими у грунто- 
знавстві методиками (Methods for determining, 2003, 2005). Для аналізу та узагальнення отриманих результатів застосовували методи математичної статистики.

Результати та обговорення. Найбільші обсяги лісорозведення останніх десятиліть збігаються 3 виконанням Державної цільової програми «Ліси України» на 2010-2015 pp. (State Target Program, 2009). Так, упродовж 2010-2014 pp. держлісгоспами під заліснення було прийнято близько 210 тис. га деградованих і малопродуктивних земель, зокрема у Поліссі - 4981,9, Лісостепу - 13540,5, Степу - 190931,9, Карпатах - 578,6 га. Внаслідок низки причин, насамперед через недофінансування, складність процедури прийняття земель, а також політичну ситуацію в Україні, зазначену Програму було реалізовано частково, а після закінчення терміну її дії цілком призупинено. На 01.01.2019 р. загальна площа прийнятих, але незаліснених земель, порівняно з 2014 р., зменшилась до 44777 га, тобто майже у п'ять разів, більшість з яких $(96,9 \%)$ припадає на підприємства степового регіону, особливо Одеського - 12710 га (29,3\%), Луганського - 12674 $(29,2)$, Херсонського - 6272 (14,5\%) ОУЛМГ (Public report, 2018) (рис. 1).

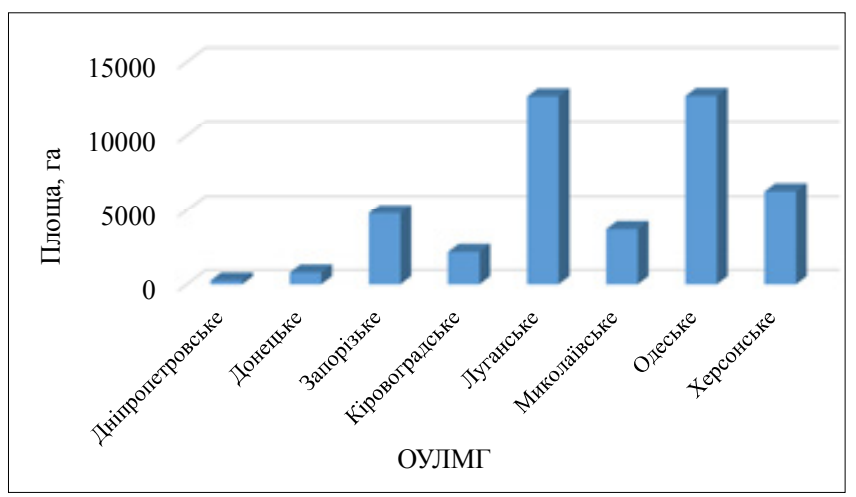

Рис. 1. Площі незаліснених земель, прийнятих ОУЛМГ для залісення станом на 01.01.2019 р.

Створення лісових насаджень у степових умовах завжди було і $є$ значною проблемою. Так, упродовж останніх трьох років (2016-2018 рр.) середня величина фактичної приживлюваності 1-3-річних лісових культур під час лісорозведення становить $60,9 \%$ за нормативної - 70,1 \% (Public report, 2018). Найвищі значення фактичної приживлюваності зафіксовано на підприємствах Кіровоградського $(78,0 \%)$, Донецького $(71,6)$, Одеського $(70,2)$, Запорізького ОУЛМГ (68,6 \%), а найнижчі - Дніпропетровського, Луганського та особливо Херсонського ОУЛМГ - 50,0, 50,1, 34,2\% відповідно.

Аналіз обсягів загиблих культур, створених під час лісорозведення у попередні роки, показав, що їхні максимальні площі зосереджені на підприємствах Донецького, Миколаївського та Херсонського ОУЛМГ, причому у Херсонському ОУЛМГ загинуло $100 \%$ культур, а загалом для степової зони їхня частка становить $61 \%$ (рис. 2). Основною причиною загибелі лісових культур є посуха, від якої на землях Дніпропетровського, Луганського та Херсонського ОУЛМГ всохло 97,3, 94,3 та 65\% деревних рослин відповідно.

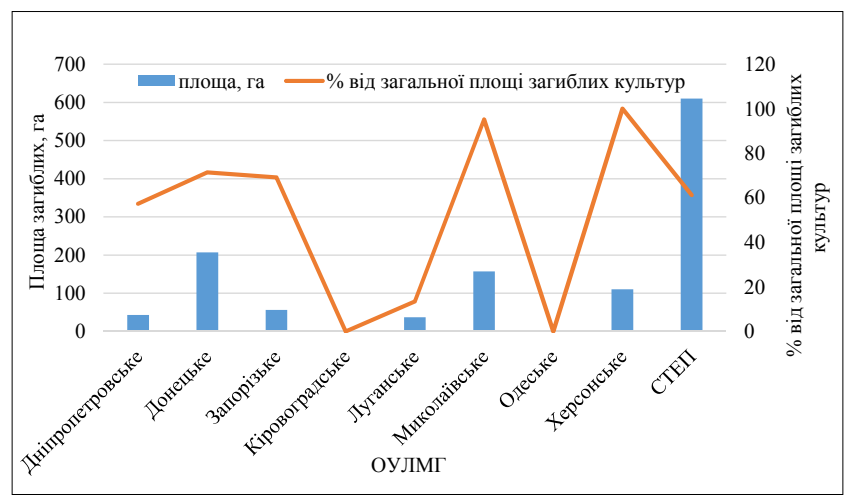

Рис. 2. Загиблі під час лісорозведення лісові культури попередніх років створення на підприємствах ОУЛМГ степового регіону (станом на 01.01.2019)

Загальна частка загиблих лісових культур від посухи у держлісгоспах степової зони становить $66,3 \%$, ще $10 \%$ загинуло від пожеж, 7,8\% - від диких тварин, 1,2 \% - внаслідок недостатнього догляду, $14,2 \%$ - 3 інших причин. Наведені дані з приживлюваності та збережуваності лісових культур свідчать про значну їхню варіабельність (див. рис. 2), яка зумовлена неоднорідністю грунтово-кліматичних умов у межах степової зони. Так, якщо грунтовий покрив підприємств, підпорядкованих Кіровоградському, Донецькому, Одеському ОУЛМГ, переважно представлений родючими грунтами чорноземного типу - чорноземами звичайними та південними, то на території Луганського, й особливо - Херсонського ОУЛМГ значною мірою поширені малопродуктивні грунти піщаного складу - дернові опідзолені, а подекуди - дефльовані примітивні початкових стадій формування (рис. 3).

Примітивні грунти, поряд із дерновими опідзоленими, поширені на аренах Нижньодніпровських (Олешковських) пісків. Дернові опідзолені грунти належать до грунтів початкових стадій опідзолення. Відомо, що так їх уперше назвав видатний ученийлісознавець Г. М. Висоцький (Migunova, 2010), їхня інша поширена назва - дернові борові (Polupan, 1981). Подібними до цих грунтів є дерново-лісові (формуються під ксерофітно-рідкотрав'яними сосняками), які виділено у національній класифікації грунтів Російської Федерації (Shishov, 2004). Дернові опідзолені грунти характеризуються недиференційованим за мулом профілем, яскраво вираженим максимумом гумусу та біогенних елементів (на фоні їх дуже низького вмісту) у верхніх горизонтах i класичним докучаєвським набором генетичних горизонтів: (А) (гумусовий), (В) (перехідний), (С) (порода), власне підзолистий горизонт відсутній (див. рис. 3). Типовою їхньою рисою $є$ деяка освітленість гумусового горизонту та наявність на глибині 4060 см горизонту жовтого (жовтувато-іржавого) забарвлення. Характерними ознаками також є літогенність (присутність вже з поверхні майже не зміненої 
грунтоутворенням материнської породи), щільність складення, безкарбонатність, незначні потужність, гумусованість і трофність, піщаний або глинисто- піщаний гранулометричний склад (табл. 2). Досить часто у їхньому профілі трапляються поховані грунти (див. рис. 3).

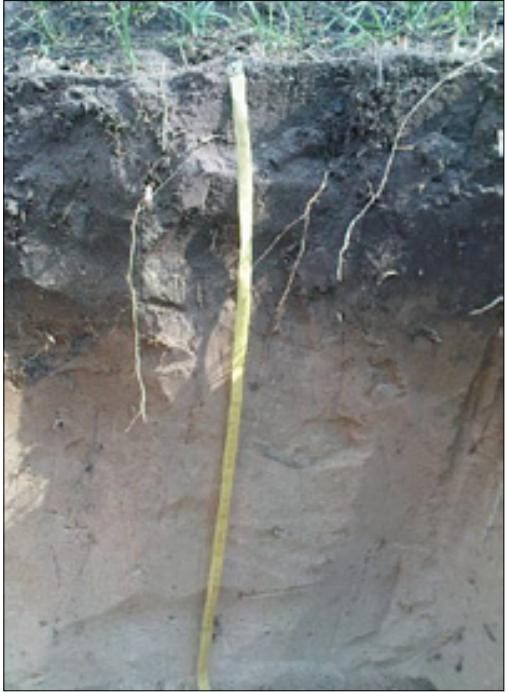

Типовий профіль дернового опідзоленого грунту

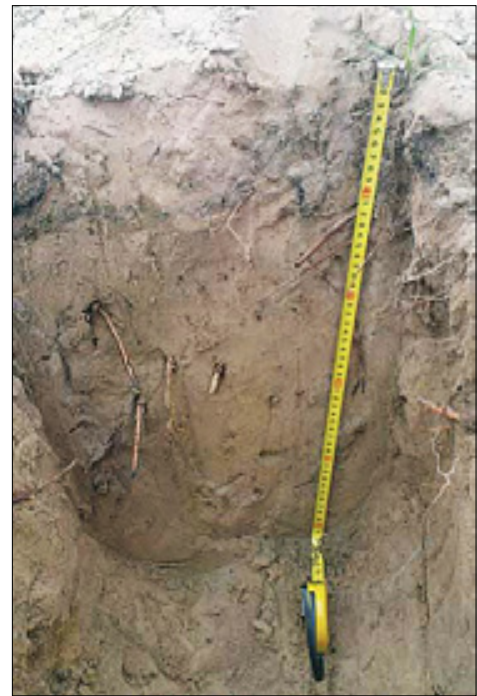

Типовий профіль дефльованого примітивного грунту

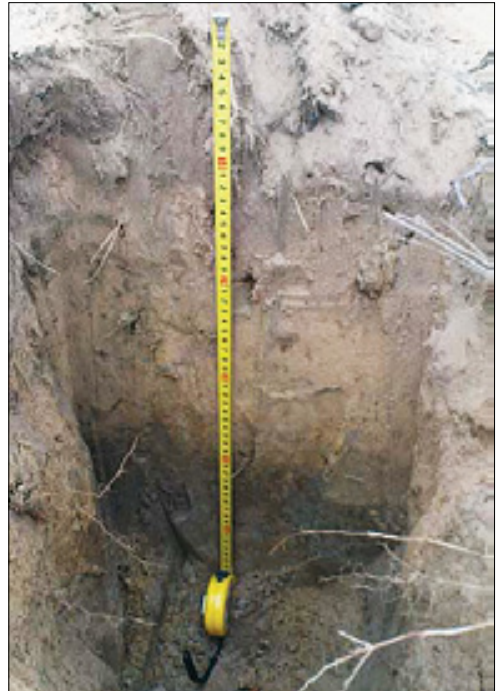

Похований (на глибині 38 см) грунт у профілі дефльованого примітивного грунту

Рис. 3. Дерновий опідзолений грунт (ДП «Ізюмське ЛГ» Ізюмське лісництво, кв. 385, вид. 4) і дефльовані слабогумусовані та негумусовані піски на аренах Нижньодніпров’я (Голопристанське лісництво кв. 16, вид. 6)

Середньопрофільні значення показників грунтів арен Степу (n - 37-92)

\begin{tabular}{|c|c|c|c|c|c|c|c|}
\hline \multirow{2}{*}{$\begin{array}{c}\text { Потужність } \\
\text { Н-горизонту, см }\end{array}$} & \multirow{2}{*}{$\begin{array}{l}\text { Вміст } \\
Ф Г, \%\end{array}$} & \multirow{2}{*}{$\begin{array}{c}\mathrm{pH} \\
\left(\mathrm{H}_{2} \mathrm{O}\right)\end{array}$} & \multirow{2}{*}{$\begin{array}{c}\mathrm{pH} \\
(\mathrm{KCl})\end{array}$} & Гумус & $\mathrm{N}$ & $\mathrm{P}$ & $\mathrm{K}$ \\
\hline & & & & \multicolumn{4}{|c|}{$\%$} \\
\hline $26 \pm 8,0$ & $5,7 \pm 0,38$ & $4,8 \pm 0,10$ & $3,8 \pm 0,06$ & $0,80 \pm 0187$ & $0,05 \pm 0,004$ & $0,02 \pm 0,003$ & $0,08 \pm 0,009$ \\
\hline
\end{tabular}

Отже, дернові опідзолені грунти лісових місцезростань об'єднують у собі групу грунтів легкого гранулометричного складу, які сформувалися під добре освітленими сосновими лісами з розвиненим трав'яним покривом (Gael, 1998, Driuchenko, 1962, Hladkyi, 1960).

Гранулометричний склад, зокрема вміст глинистих часток, $є$ одним із основних чинників, який визначає лісорослинний потенціал грунтів, особливо соснових місцезростань (Raspopina, 2017). За результатами наших досліджень, збільшення вмісту фізичної глини у гумусовому шарі легких грунтів на $1 \%$ сприяє підвищенню середньої висоти соснових деревостанів приблизно на 0,6 м (Raspopina, 2011). Доведено, що гранулометричний склад піщаних грунтів у зоні Північного (Луганська та Харківська обл.) та Сухого Степу (Херсонська обл.) є подібним та характеризується домінуванням фракції середнього піску у доволі вузькому діапазоні значень $-61,0$ та 65,8 \% відповідно (рис. 4).

Відомо, що саме піщані грунти є найуразливішими щодо дефляції (Scientific and applied bases, 2010). В Україні провінція активної дефляції розташована на південному сході (Донецька, Луганська та південні частини Миколаївської, Запорізької й Херсонської областей), тобто саме там, де зосереджені найбільші площі прийнятих, проте незаліснених земель (див. рис. 1). 3 огляду на те, що під час дефляції відбувається механічна руйнація та переміщення грунту, однією з основних діагностичних ознак його еродованості є зміна потужності генетичних горизонтів, насамперед гумусового, або ж потужності усього грунтового профілю (Sobolev, 1955). Унаслідок вітрової ерозії утворюються дві зони - дефляції (звідки грунт видувається) та акумуляції (де він нагромаджується). Якщо дефляції піддаються грунти чорноземного типу, то одним із основних маркерів ступеня їхнього руйнування $\epsilon$ зменшення потужності Н-горизонту. Так, під час слабкої дефляції цей горизонт скорочується менш як на $10 \%$, середньої-10-20\%, сильної - понад 20 \% (Prymak, 2001). Визначити тільки за цією ознакою еродованість піщаних грунтів у степових умовах доволі проблематично внаслідок низки причин, зокрема - здебільшого дуже незначної потужності гумусового горизонту (подекуди він взагалі відсутній або перебуває на стадії формування) та її високої варіабельності через складний рельєф сухих арен. Насамперед виникають труднощі під час вибору грунту, профіль якого б слугував еталоном (контролем) оцінювання 
рівня дефляції. Тому як основний маркер дефляції піщаних грунтів ми пропонуємо використовувати не потужність, а один із головних морфологічних показників грунту - забарвлення, а також вміст фізичної глини у горизонті, який виходить на поверхню (табл. 3). Вибір забарвлення як маркера зумовлений різкими переходами за кольором між генетичними горизонтами у верхній частині профілю. Так, у посушливому кліматі забарвлення піщаних грунтів здебільшого змінюється від світлосірого у Не-горизонті до брудно-жовтого (жовтого, жовтувато-іржавого) у перехідному (Ph) та світложовтого (жовтувато-сталевого) у Р-горизонті.

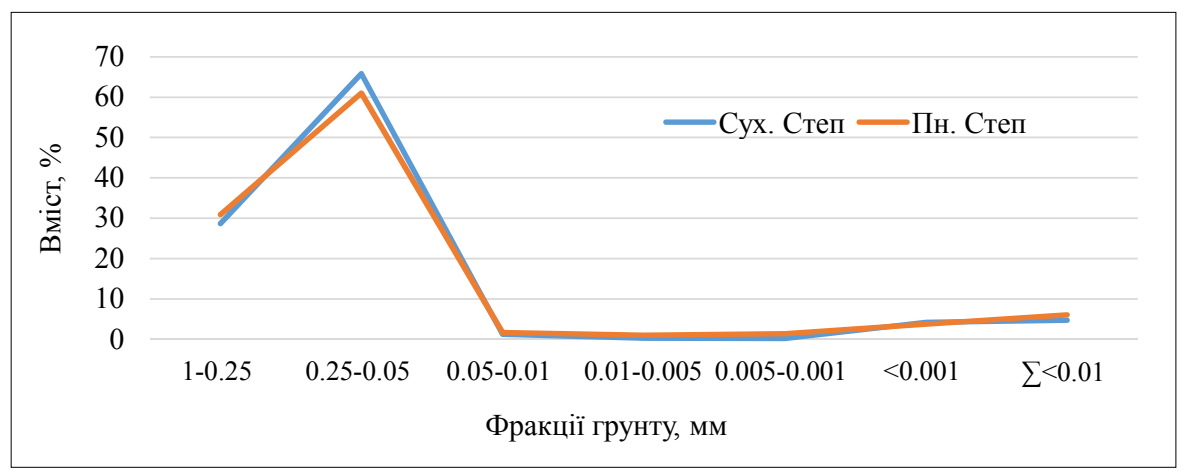

Рис. 4. Гранулометричний склад грунтів піщаного складу в степових умовах, \% $(\mathrm{n}-92)$

\section{Визначення ступеня дефляції і трофності грунтів піщаного складу у зоні інтенсивної дефляції} (Південний Схід України)

\begin{tabular}{|c|c|c|c|c|c|}
\hline \multirow[t]{2}{*}{ Ступінь дефляції } & \multicolumn{2}{|c|}{ Горизонт грунту, задіяний в ерозійному процесі } & \multicolumn{3}{|c|}{$\frac{\text { Трофотоп }}{(\text { вміст } Ф Г, \%)}$} \\
\hline & символ & забарвлення & A & B & $\mathrm{C}$ \\
\hline слабкий & $\mathrm{He}$ & світло-сірий & $\frac{\mathrm{A}}{<5}$ & $\frac{\mathrm{B}}{5-7}$ & $\frac{\mathrm{C}}{7-12}$ \\
\hline середній & $\mathrm{Ph}(\mathrm{HP})$ & брудно-жовтий (жовтий) & $\frac{\mathrm{A}}{<5}$ & $\frac{\mathrm{B}-\mathrm{A}}{5}$ & $\frac{\mathrm{C}-\mathrm{B}}{7}$ \\
\hline сильний & $\mathrm{P}(\mathrm{Ph})$ & світло-жовтий & $\frac{\mathrm{A}}{<5}$ & $\frac{\mathrm{A}}{<5}$ & $\frac{\mathrm{B}}{5-7}$ \\
\hline
\end{tabular}

Щодо використання вмісту фізичної глини, то цей показник $\epsilon$ найінформативнішим як під час визначення ступеня дефляції грунту, так і загалом його лісотипологічного оцінювання. Зважаючи на те, що наслідком дефляції є зниження родючості грунту, то, визначаючи ступінь ерозійного впливу, ми фактично оцінюємо його лісорослинний потенціал (див. табл. 3). Зауважимо, що наведені у табл. 3 величини вмісту фізичної глини, за якими визначається трофотоп ділянки, відповідають певному різновиду грунту: $<5$ - пісок, 5-7 - пісок глинистий, 7-12\% - супісок легкий (Raspopina, 2017). Такий підхід дає змогу визначити трофотоп ділянки вже під час натурного дослідження як за забарвленням грунту, так і за допомогою польового «сухого» методу визначення гранулометричного складу. Щодо вологості піщаних грунтів, то вона значною мірою залежить від рельєфу території, проте здебільшого у степових умовах переважають сухі місцезростання.

Висновки. Для зупинення деградації грунтового покриву необхідно вилучити з обробітку від 6,5 до 10 млн га малопродуктивних земель, насамперед у Степу, територія якого $\epsilon$ найбільш розораною в Україні, із наступною їх консервацією і трансформацією у лісові та кормові угіддя. Найбільші обсяги лісорозведення останніх десятиліть збігаються $з$ виконанням Державної цільової програми
«Ліси України» на 2010-2015 pр., упродовж якої під заліснення було прийнято близько 210 тис. га деградованих і малопродуктивних земель, здебільшого (понад 190 тис. га) держлісгоспами степового регіону. На 01.01.2019 р. загальна площа прийнятих, але незаліснених земель, порівняно з 2014 р., зменшилась до 44777 га, причому абсолютно більша їх частина $(96,9 \%)$ припадає на підприємства степової зони.

Середня величина фактичної приживлюваності 1-3-річних лісових культур, створених у Степу впродовж 2016-2018 рр. під час лісорозведення, становить $60,9 \%$, що значно нижче від нормативного показника $(70,1 \%)$. Вкрай низькою є також збережуваність культур. На 01.01.2018 р. загинуло $61,2 \%$ культур попередніх років створення, причому здебільшого $(66,3 \%)$ - від посухи.

Грунти легкого (піщаного, глинисто-піщаного) гранулометричного складу унаслідок несприятливих фізичних та агрохімічних властивостей (щільність складення, безструктурність, незначні гумусованість і вологоємність, вкрай низький вміст поживних елементів тощо) відносять до категорії малопродуктивних. Рівень їхньої трофності залежить від вмісту глинистих часток та підвищується з його зростанням у межах від борового до сугрудового типів місцезростань. 
Грунти арен, унаслідок складного рельєфу, характеризуються високою варіабельністю та незначною потужністю гумусового горизонту, який подекуди взагалі перебуває на стадії формування, що ускладнює оцінку ступеня їхньої еродованості. Як основні маркери дефляції піщаних грунтів пропонуємо використовувати вміст фізичної глини у верхньому горизонті та його забарвлення. Зважаючи на те, що наслідком дефляції є зниження родючості грунту, визначаючи ступінь ерозійного впливу, ми фактично оцінюємо його лісорослинний потенціал.

\section{References}

Baliuk, S.A., \& Tovazhnianskyi, L. L. (2010). Scientific and applied bases of soil protection against erosion in Ukraine. Kharkiv: NTU «KhPI» (in Ukrainian).

Biallovich, Yu. P. (1972). Standards of optimal forest cover on plain part of the Ukrainian SSR. Forestry and agroforestry, 28, 54-65 (in Russian).

Chornyi, S.G., \& Chorna, T.M. (2008). Dust storm March 23-24, 2007 in the southern regions of Ukraine, causes and consequences. Protection of soil fertility: Bulletin of Articles, 4, 158-170 (in Ukrainian).

Driuchenko, M. M. (1962). Fastening and afforestation of sands. Kyiv: State Publishing house agricultural literature of the Ukrainian SSR (in Russian).

Gael, A. G., \& Smirnova, L. F. (1999). Sands and sandy soils. Moscow: Geos (in Russian).

Hladkyi, A.S. (1960). Soil-forest conditions of the Lower Dnieper (Oleshkovsky) sands. Scientific works of UkrNIIILHA, 20, 68-79 (in Ukrainian).

Methods for determining the composition and properties of soils. Book 1. (2003). Kharkiv: NSC ISSAR (in Ukrainian).

Methods for determining the composition and properties of soils. Book 2. (2005) Kharkiv: NSC ISSAR (in Ukrainian).

Migunova, E. S. (1978). Forest plantations on saline soils. Moscow: Forest industry (in Russian).

Polupan, N.I., Kysil, V.D., Kovalishin, D. I., Dusanovsky V.L., Vernander, N.B.,... Andrushchenko, H.A. (1981). Field determinant of soils. Kyiv: Harvest (in Russian).

Prymak, I. D, Vakhniy, S.P., Bomba, M. Ya., Timoshchuk, A.S., Gudz, V.P., Roshko, V.G. ... Lutsyuk, I. O. (2001). Erosion and soil deflation and measures to combat. Bila Tserkva: Bilotserkivsky agricultural university (in Ukrainian).

Publicreportofpublicagency forestresourcesof Ukraine in 2018 (2018). Available at: from http: // drive. google.com/file/d/194P-skQpV9fI1BOdYBGSKix_ ulyHlfhQ/view (in Ukrainian).

Raspopina, S.P. (2017). The scientific basis of estimating the potential of soils for forest growth and the suitability of soils for growing forest plantations in plain parts of Ukraine (Doctoral dissertation, Ukrainian National Forestry University, Lviv, Ukraine). Available at: http://old.nltu.edu.ua/ docs/svr/d35.072.02/raspopina /aref_raspopina.pdf (in Ukrainian).

Sayko, V.F. (2008). The scientific rationale for agriculture in the context of climate change. Bulletin of agricultural science, 9, 5-10 (in Ukrainian).

Shishov, L. L, Tonkonogov, V. D, Lebedev, I.I. et al. (2004). Classification and diagnostics of Russian soils. Smolensk: Oikumena (in Russian).

Sobolev, S. S. (1954). The nomenclature of washed-off (eroded) soils. Soil studies and compilation of soil maps, 13-24 (in Russian).

State Target Program «Forests of Ukraine» for 20102015. (2009). Available at: http://zakon4.rada.gov. ua/laws/show/977-2009-п (in Ukrainian).

\section{Песчаные почвы и состояние лесоразведения в зоне интенсивной дефляции Украины}

\section{С.П. Распопина}

Показано, что чрезмерная распаханность земель вызвала интенсивное развитие эрозионных процессов и как следствие - деградацию почвенного покрова Украины. Самым действенным средством замедления и предупреждения деградации почв является оптимизация соотношения площади пашни и экологически стабилизирующих угодий. Это достигается путем исключения из обработки деградированных и малопродуктивных земель с последующей их консервацией и трансформацией в лесные и кормовые угодья. По разным оценкам изъятия требует от 6,5 до 10 млн га пашни, в основном в Степи, территория которой наиболее распахана. Установлено, что максимальные объемы лесоразведения последних десятилетий совпадают с выполнением Государственной целевой программы «Леса Украины» на 2010-2015 гг. В течение этого периода под облесение было принято около 210 тыс. га малопродуктивных земель, в основном $(90 \%)$ гослесхозами степных регионов. По состоянию на 01.01.2019 г. общая площадь принятых, но необлесенных земель, уменьшилась до 44777 га, причем абсолютно большая их часть $(96,9 \%)$ приходится на предприятия степной зоны. Приведены показатели приживаемости и сохранности лесных культур, созданных при лесоразведении в Степи, которые значительно ниже нормативных. Так, в течение последних трех лет (2016-2018 гг.) средняя величина фактической приживаемости 1-3-лет-

\footnotetext{
Распопина Светлана Петровна - член-корреспондент Лесной академии наук Украины доктор сельскохозяйственных наук, старший научный сотрудник, заведующий кафедрой лесных культур и мелиораций. Харьковский национальный аграрный университет им. В.В. Докучаева, п/в «Докучаевское-2» Харьковской обл., 62483, Украина. Тел.: 0572- 99-72-56, +38-068459-64-23. E-mail: s_raspopina@ukr.net ORCID: http://orcid.org/ 0000-0002-1880-9364
} 
них лесных культур при лесоразведении составляет $60,9 \%$, при нормативном показателе в 70,1\%. Максимальные площади погибших при лесоразведении культур также находятся в зоне Степи, в частности на государственных предприятиях Донецкого, Николаевского и Херсонского областных управлений лесного и охотничьего хозяйств (ОУЛОХ), причем в Херсонском ОУЛОХ в 2018 г. погибло $100 \%$ культур, а в целом по степной зоне их долевое участие составляет $61 \%$. Охарактеризованы дерновые оподзоленные на древнеаллювиальных (или эоловых) песках почвы, которые, вследствие крайне неблагоприятных для сельскохозяйственных культур свойств (бесструктурность, низкие влагоемкость, гумусированность, трофность), передаются под облесение в разных регионах Украины. В южно-восточной части Украины, в частности, на аренах Нижнеднепровских (Олешковских) песков, наряду с дерновыми оподзоленными, широко распространены примитивные почвы. Вследствие ряда природно-климатических условий, эта часть Украины является провинцией активной дефляции. Она охватывает Донецкую, Луганскую и южные части Николаевской, Запорожской и Херсонской областей. На их территории также сосредоточены наибольшие площади принятых, но необлесенных земель. Обосновано, что в степных условиях, определение степени дефляции песчаных почв по трансформации гумусового горизонта является довольно проблематичным, вследствие, прежде всего, очень незначительной его мощности, а иногда полного отсутствия, а также из-за сложного рельефа сухих арен. Показано, что уровень плодородия песчаных почв зависит от содержания глинистых частиц, поэтому этот показатель является наиболее информативным как при определении степени их дефляции, так и при лесотипологической оценке в целом. Предложены маркеры для оценивания дефляции песчаных почв и их лесорастительного потенциала.

Ключевые слова: ветровая эрозия; степь; малопродуктивные земли; облесение; лесные культуры; содержание физической глины.

\section{Sandy soils and the state of afforestation in the zone of intense deflation in Ukraine}

\section{S. Raspopina ${ }^{1}$}

It is shown that excessive plowing of land caused an intensive erosion processes and, as a result, degradation of soil cover in Ukraine. The most effective way of

Svitlana Raspopina - Corresponding Member of the Forest Academy of Sciences of Ukraine, Grand $\mathrm{PhD}$ of Agricultural Sciences, Senior Researcher, Head of the Department of Forest Crops and Meliorations. Kharkov National Agrarian University after V.V. Dokuchaev. The village «Dokuchaevske-2», Kharkiv district, Kharkiv region, 62483, Ukraine. Tel.: 0572-99-72-56, +38-068-459-64-23.E-mail: s_raspopina@ukr.net ORCID: http:// orcid.org/ 0000-0002-1880-9364 slowing down and preventing soil degradation is to optimize the ratio of arable land to ecologically stabilizing lands. It's achieved by transforming degraded and unproductive lands from using, followed by their conservation and transformation into forest and forage lands. According to various estimations, subject to seizure from 6.5 to 10 million hectares of arable land, mainly in the Steppe, which territory is most plowed. Some of these lands have already been transferred for afforestation. It has been established that the largest areas of afforestation in recent decades coincide with the implementation of the State Target Program «Forests of Ukraine» for 2010-2015. During this period, about 210 thousand hectares of unproductive lands, mostly $(90 \%)$ by state forestry enterprises of the steppe zone, were taken under afforestation. As of January 1,2009 , the total area of land designated for afforestation but not covered by forest decreased to $44777 \mathrm{ha}$, and most of them (96.9\%) are located in the steppe zone. The indicators of taking root and safety of forest crops created during afforestation in the steppe which have been presented are significantly lower than the normative ones. So over the past three years (20162018 ), the average value of actual survival of 1-3-yearold forest crops during afforestation is $60.9 \%$, while the normative indicator is $70.1 \%$. The maximum areas of crops lost during afforestation are also located in the Steppe zone, in particular at state enterprises of the Donetsk, Mykolaiv and Kherson Regional Forestry and Hunting Departments (RFHD), and in 2018 in Kherson RFHD $100 \%$ of the crops lost, and a whole, their share is $61 \%$. Characterized soddys podzolized soils of claysandy composition on ancient alluvium sandy, which, due to extremely unfavorable properties for crops (the structure less, low - moisture capacity, humus content, trophicity) are largely transmitted under afforestation. In the southeastern part of Ukraine, in particular, in the arenas of the Nizhnedneprovsky (Oleshkovsky) sands, primitive soils are widespread, along with sod podzolized ones. Oleshkovsky sands is one of the largest sand massifs in Ukraine and is considered the second largest desert in Europe. Due to a number of climatic conditions, this part of Ukraine is a province of active deflation. It covers Donetsk, Lugansk and southern parts of Mykolaiv, Zaporizhzhya and Kherson regions. On the territory of these regions also the largest area of non-afforested land is concentrated. It is substantiated that in the steppe conditions, determining the degree of deflation of sandy soils by the transformation of the humus horizon is rather problematic, due, first of all, to its very insignificant thickness, and sometimes its complete absence, and because of the complex relief of dry arenas. It was shown that fertility level of these soils is completely dependent on the content of clay particles, therefore this indicator is the most informative both in determining the degree of deflation soils and in general their typological assessment. The markers proposed for assessing their deflation and, in general, forest growth potential.

Key words: wind erosion; steppe; low productive lands; afforestation; forest cultures; content of clay particles. 